\title{
AN ANALYSIS OF GRAMMATICAL ERRORS MADE BY THE SEVENTH GRADE STUDENTS OF SMP NEGERI 2 SUKAWATI IN WRITING DESCRIPTIVE TEXTS IN THE ACADEMIC YEAR 2018/2019
}

\author{
I.P.B. Erlangga ${ }^{1}$, I.W. Suarnajaya ${ }^{2}$, P.A.K. Juniarta ${ }^{3}$ \\ Program Studi Pendidikan Bahasa Inggris \\ Universitas Pendidikan Ganesha \\ Singaraja, Indonesia \\ e-mail: baguserlangga89@gmail.com,w suarna@yahoo.com, adiputu108@gmail.com
}

\begin{abstract}
Abstrak
Penelitian ini bertujuan untuk menggambarkan jenis kesalahan dalam teks deskriptif siswa kelas tujuh dan mengidentifikasi penyebab kesalahan. Ada dua permasalahan dalam penelitian ini, yaitu: (1) Apa jenis kesalahan grammar yang dilakukan oleh siswa kelas tujuh SMP Negeri 2 Sukawati dalam menulis teks deskriptif? dan (2) Apa penyebab kesalahan grammar yang dilakukan oleh siswa kelas tujuh SMP Negeri 2 Sukawati dalam menulis teks deskriptif ?. Instrumen yang digunakan adalah peneliti, tugas menulis, pedoman, panduan wawancara, dan perekam ponsel. Hasil penelitian ini menunjukkan bahwa ada lima jenis kesalahan yang ditemukan dalam teks deskriptif siswa, yaitu: omission, addition, misformation, misordering, and spelling. Total kesalahan adalah 541 kesalahan. Ditemukan bahwa omission adalah kesalahan yang paling sering dilakukan oleh siswa. Ada tiga penyebab kesalahan yang ditemukan dalam penelitian ini, yaitu: carelessness (40,67\%), first language interference $(53,42 \%)$, dan translation (5,91\%).
\end{abstract}

Kata kunci: kesalahan-kesalahan grammar, teks deskriptif, menulis, bahasa Inggris

\begin{abstract}
This study aimed at describing the types of errors in seventh grade students' descriptive texts and identifying causes of errors. There are two research questions in this study, namely: (1) What are types of grammatical errors made by seventh grade students of SMP Negeri 2 Sukawati in writing descriptive texts? and (2) What are the causes of grammatical errors made by seventh grade students of SMP Negeri 2 Sukawati in writing descriptive text?. The data for study were collected by document study, interview method, and recording. The instruments were researcher, writing task, guideline, interview guide, and mobile recorder. The results of this study showed that there were five types of errors found in students' descriptive writing, namely: omission, addition, misformation, misordering, and spelling. The total number of errors was 541 errors. There were three causes error found in this study, namely: carelessness (40.67\%), first language interference (53.42\%), and translation (5.91\%).
\end{abstract}

Keywords: grammatical errors, descriptive texts, writing, English.

\section{INTRODUCTION}

Governor of Indonesia inserts English in Indonesia's education and he employs it as a formal education for all Indonesian students (Putri, 2013:1). English education for Indonesian students starts from elementary schools until colleges. In junior high school, English has been confirmed by Government of Indonesia as a required subject taught to students. It is based on the Decree of Education Ministry number 24 in 2006 about School Based Curriculum and Standard of Content. There are four English skills which are learned by Indonesian students in English class, namely: reading, listening, speaking, reading, and writing. However, writing is recognized as the most complex skill to be mastered by people (Al-Shujairi \& Tan, 2017:122)

Writing is one of English skills that are taught by teacher to students in Indonesia. Writing is one of the learning materials included in every teaching and learning syllabus (Harmer, 
2004:31). This skill is categorized as a productive skill (Golkova \& Hubackova, 2014:478). Writing can be described as a cognitive activity to find ideas, how to express the idea, and organize the ideas into statement and paragraph obviously (Nunan, 2003:88). In writing class, students learn several subjects. Students learn syntax, grammar and vocabulary in writing class which will help them to produce a good foreign language writing (Hermini, 2015:89). From all subject, grammar comes as the most difficult and complicated subject to be mastered by students (Belo, 2017:513).

Students who want to create sentences using foreign language need to know about grammar rules in a language first. It is because understandable sentences are produced by students based on the grammatical rules (Furtina, Fata,\& Fitrisia, 2016:252). According to Greenbaum and Nelson (2002:1), grammar is a set of rules in a language that allow a person to combine several words into larger unit. It means that grammar in a language should be known well if a person wants to create understandable sentences.

Foreign language learners find difficulty in applying grammar rules of a target language into text and they may commit error. Limited knowledge about grammatical rules and rare occasion to use the rules in interaction start the error production from foreign language learners (Silalahi, 2014:152). According to Moqimipour \& Shahrokhi (2015:124), errors can be seen as inadequate knowledge about foreign language rules which start the production of unacceptable written or oral linguistic items. As the result of errors, readers may create misinterpretation about the meaning that the writer wants to convey to readers.

An error analysis is needed to be done by teachers to describe the errors committed by students and to know the causes of errors committed by students. According to Divsar and Heydari (2017:143), error analysis (EA) is a way to gather errors found in students' language, decide either the errors are systematic or not, and clarify what the reasons behind errors found in students. It means that error analysis is an approach done by someone to sum up all errors that appear in students. Not only that, error analysis also tries to discover whether the errors are systematically found or not. And the last, error analysis describes the causes of errors that the teacher has found.

Doing an error analysis can provide certain kinds of benefits. Several experts have expressed their arguments about the benefits of error analysis. Khan \& Khan (2016:235) state that error analysis can assist teachers to find out the difficult area of English subject in which students find difficulty in learning a language and it also assists teachers, learners and syllabus designers in discovering beneficial remedial material for solving the errors. Jabeen, Kazemian, \& Mustafai (2015:53) also argue that error analysis gives a deep insight for more understanding about the process of language learning done by students. The last benefit comes from Nzama. According to Nzama(in Agustina \& Junining, 2015:3), error analysis is beneficial for the teachers, syllabus designers, and textbook writers since it can reveal the problems faced by learners in learning a language. So, there are lots of benefits that can be gained by teachers as well as other people from doing an error analysis.

Recently, there had been several studies about error analysis done by some experts. The first research was a research from Yosi Founisce Putri in 2013. The result was most of the students made errors of omission. The omission in her study consisted of omission of verb inflection (marker s/es), omission of auxiliary verbs (is, am, are) and other omission. Another research was a research from Komang Sri Wahyuni in 2016. The most frequent error committed by students in writing descriptive texts was misformation. The error of misformation consisted of misformation of gerund, an article, personal pronoun, possessive pronoun, and words. Each of the previous research had different result.

Related to phenomena of error in using a language, there was a unique phenomenon of error in SMP Negeri 2 Sukawati. SMP Negeri 2 Sukawati is one of the favorite junior high schools in Sukawati. This school is located in Singapadu village. SMP Negeri 2 Sukawati's location is near several tourism objects such as Bali Zoo, Bali Bird Park, and Bali Kecak Dance. Not only that, the school's location is in the middle of Singapadu village. Singapadu village is recognized by people as the home of silver jewelries and antique statues. Many tourists, when they come to Sukawati, visit this village to search and buy unique jewelries made from silver 
and statues. Tourists and students in SMP Negeri 2 Sukawati often make interactions to each other when they meet. The interactions can be in the form of giving greeting, talking, and etcetera. It was assumed that students already know how to use English well. But, after doing preliminary observation in this school, there were several errors found in students' descriptive texts. These results were also strengthened by an argument from one of the English teachers in SMP Negeri 2 Sukawati. She expressed that the students of SMP Negeri 2 Sukawati have low competency in English especially in writing. Students' daily score and their writing assignments showed that they have low competency in writing. After discovering those errors, it was interested to do a deeper analysis about the types and causes of errors committed by students of SMP Negeri 2 Sukawati.

To do an error analysis especially error analysis in writing, a person should decide on what kind of written text that the he or she wants to analyze using error analysis. Kinds of written texts in Indonesia have been arranged in law of Indonesia. Kinds of written texts for writing in Indonesia have been listed at Peraturan Menteri Pendidikan Nasional Nomor 23 Tahun 2006. The law says "using every kind of written texts to express thought, feeling, and information in the form of narrative text, descriptive, expository, argumentative, speech, summary, report, and other literary works in form of poetry, short story, drama, critique, and essay". At last, descriptive text was the focus of this research.

Descriptive text was chosen because of several considerations. First, The tense that is used in descriptive text. Descriptive text uses simple present tense in its construction. Generally, simple present tense is a tenses used in daily life interaction (Taslim, 2015:147). Based on the preliminary observation, students in SMP Negeri 2 Sukawati were active enough in using this kind of tense in interaction with their friends rather than using other tenses. So, it was assumed that students will have no problem to produce descriptive texts which use simple present tense because they already know how to use simple present tense. The second reason was descriptive text was the first English text students learned in junior high school. Based on the syllabus of the seventh grade 2017 revised edition, descriptive text comes as the first type of English text in junior high school students. So, it is believed that students from the seventh grade until ninth grade already have prior knowledge about this text.

SMP Negeri 2 Sukawati is a junior high school which has three student grades. Those grades are the seventh, eighth, and ninth grade students. In doing an error analysis in this school, the seventh grade students of SMP Negeri 2 Sukawati was chosen as the subjects of research. This grade was selected because the result of preliminary observation. It was seen that the seventh grade students of SMP Negeri 2 Sukawati were more active in using English rather than other grades. The seventh grade students also made more and various errors in using English rather than other grades. This result of preliminary observation was also strengthened by some statements from a teacher of SMP Negeri 2 Sukawati. She said that the seventh grade students in this school are more active to use English. Not only that, she said that the production of grammatical error in this grade is a common problem. Furthermore, the seventh grade students of SMP Negeri 2 Sukawati were currently learning descriptive text in this semester. In their descriptive texts, one of the students wrote a sentence: "He like playing football". Another student made a sentence like this: "He has a body big".

Considering the benefits got from doing an error analysis and errors found in the seventh grade students' descriptive text, there was an interest for conducting a research about error analysis to junior high school students. The research analyzed grammatical errors found in junior high school students especially the seventh grade students when they wrote descriptive texts.

There were several theories used in this research. The theories were grammatical error, types of grammatical error, and cause of error. There have been several definitions of grammatical error stated by some experts. According to Burt and Kiparsky (in Putri \& Dewanti, 2017:2), grammatical error is an error that violates grammatical rules in a language and it makes someone's writing becomes not good to be seen by readers. It means that grammatical error is an error that makes a written text of someone not appropriate enough to be read by reader because error breaks all grammatical rules in a language. In making a written text, a 
writer should consider grammatical rules that he or she will use in his or her written text. Grammatical rules help writer to create an understandable sentence. If a writer does not follow grammatical rules in certain language correctly, he or she fully makes error in his or her writing.

On the other hand, Hsu has his opinion about grammatical error. According to Hsu (2013:513), grammatical error is a deviation from learners in applying certain language rules which consists of incorrect forms, semantics meaning, and uses of foreign language because of incomplete comprehension from learners about foreign language's rules. It means that error is a deviation because of low understanding about foreign language' rules. Foreign language has its own rules to be known by learners. The rules should be comprehended well before learners try to use foreign language. Applying foreign language may come to failure if learners have low knowledge about the rules of foreign language.

Based on the several definitions of grammatical error argued by some experts above, it is recognized that grammatical error is a deviation which consists of incorrect forms, semantics meaning, and uses of foreign language because of incomplete comprehension from learners about foreign language's rules and it makes someone's writing become not good to be seen by reader.

The theory used for analyzing error in this research was theory from Dulay, Burt, and Krashen (1982:154) assisted with spelling error from Sawalmeh's theory (2013:12). Dulay, Burt, and Krashen (1982:154) state there are four types of error, namely: (1) Omission, (2) Addition, (3) Misformation, and (4) Misordering. Omission is the missing of an item which must occur in the sentence to form correct sentence. Addition is the contrast of omission. In omission, it is about the missing of an item which must occur. But, in addition, it is the presence of an item which must not occur in a sentence to make it an appropriate sentence. Misformation is the implementation of wrong form of items in right place of the sentence. This happens when learners choose wrong forms of phoneme, morpheme, structure, or vocabulary. Then, they place the wrong form in the right place where right form should be added in the sentence. Misordering is the incorrect placement of a morpheme or group of morphemes in sentence. Misordering error happens when learners make an incorrect sentence because the sequence of items are not in the correct placement. Spelling is related to the combination of letters to construct a word (Sawalmeh, 2013:12)

For analyzing the cause of error, Norrish's theory was implemented. Norrish (1983:47) states that there are three causes of errors, namely: carelessness, first language Interference, and translation. Carelessness is mostly linked with the deficiency of motivation from students. In teaching and learning process done by teacher in the class, some students may lost their motivation towards it. Possibly, either the material or teacher's teaching style do not match with the students. As the result, they don't comprehend the material taught by teacher because they have no enough motivation to learn. First language interference is the second cause of error. Norrish (1983:47) explains that learning either native or foreign language is considered as habit formation. When a person decides to learn a new habit for himself or herself, his or her old habit has possibility to interrupt him or her in learning it. His or her old habit will come to disturb the person in learning. Then, this cause of error is known as first language interference. Translation has been categorized as the most common cause of error. Students make foreign language sentences by translating their native language sentences word by word.

There are two research problems within this research. Those research problems are: (1) What are the types of grammatical errors made by the seventh grade students of SMP Negeri 2 Sukawati in writing descriptive texts? and (2) What are the causes of grammatical errors made by the seventh grade students of SMP Negeri 2 Sukawati in writing descriptive text?. Related to the research problems stated previously, two research objectives are formulated. The objectives are: (1) To describe the types of grammatical errors that were made by the seventh grade students of SMP Negeri 2 Sukawati in writing descriptive texts and (2) To find out and describe the reasons why the seventh grade students of SMP Negeri 2 Sukawati made error in writing descriptive texts. 


\section{METHOD}

This part would review the methods to obtain the data, sources of data, and how to analyze the data.

The first is the methods to obtain the data for this research. There were several methods utilized to get the data. The methods were document study, interview method, and recording. Document study in this research was the written task made by seventh grade students of SMP Negeri 2 Sukawati in academic year 2018/2019. An action of collecting descriptive texts made by the students was done and then analyzed them to reveal the errors. The second is interview method. This method was used to find out the reason behind students' errors. All students had been interviewed one by one after the writing task. The last method is recording. It was conducted to record the answers from students when they were being interviewed. From the recording, the researcher also could create the transcription for revealing the cause of error. So, those are the methods for gaining the data in this research.

Second is sources of data. Sources of data were important for this research in order to gain the result of research. The source of data could be gained by giving writing task and interview guide to students. The subjects that were given writing task and interview guide were students of VII G class at SMP Negeri 2 Sukawati in the academic year 2018/2019. There were various errors found in VII G students' descriptive texts rather than the other seventh grade classes in SMP Negeri 2 Sukawati. This class consisted of 36 students. Furthermore, the objects of this research were types of grammatical errors and the causes of errors in the descriptive texts from 36 students of class VII G at SMP Negeri 2 Sukawati in academic year 2018/2019. In this research, there were several criteria that should be fulfilled from the writing of the students. These criteria act as the consideration that writing from students can be analyzed. The criteria were: (1) The written texts from students should contain errors inside of them, (2) The written texts from students should consist of two paragraphs, and (3) The written texts from students should describe something (family member).

Third is how to analyze data. This research used Gass and Selinker's (2008:103) steps of error analysis. The diagram of the steps can be seen below.

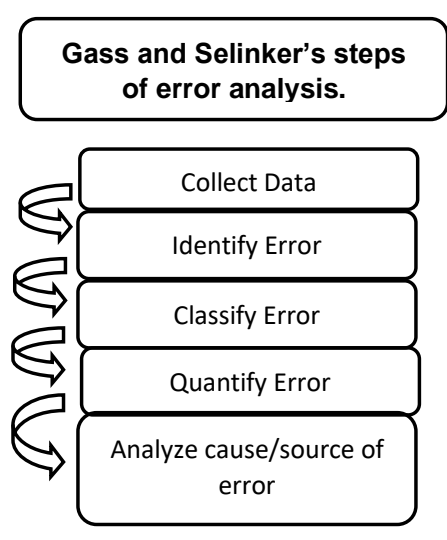

After getting the data, first thing to do is identifying the grammatical error. In this step, the collected data were identified to reveal grammatical errors in students' writing. Second step is classifying the data. The grammatical errors found were classified into each type of grammatical errors. The third step is calculating the grammatical error. After classifying the entire errors to the place where they belong, the errors were calculated. Calculating the errors gave the data about the total numbers of errors found as well as the percentage of errors. The calculation of error's percentage uses formula below.

Adapted from Putri (2013)

$x=\frac{n}{n t} X 100 \%$

Where: 
$\begin{array}{ll}\mathrm{X} & : \text { percentage of errors type } \\ \mathrm{N} & \text { : the number of a particular type of error } \\ \mathrm{Nt} & : \text { the total number of all types of errors }\end{array}$

The fourth step is analyzing the cause of error. The cause of error was analyzed through relating the error with the theory about the causes of errors and confirmed by the result of the interview. The fifth step is reporting the analysis' result. After analyzing the data, the results were described in descriptive way. The last is drawing conclusion. At last, the conclusion of research was created based on the result of analysis.

\section{FINDINGS AND DISCUSSIONS} below.

From the analysis, it was found several types of error. The types of error can be seen

Table 1. the calculation results of students' errors

\begin{tabular}{cccc}
\hline No. & $\begin{array}{c}\text { Types of } \\
\text { Error }\end{array}$ & $\begin{array}{c}\text { The } \\
\text { Number } \\
\text { of } \\
\text { Errors }\end{array}$ & $\begin{array}{c}\text { Percentage } \\
\text { of Error }\end{array}$ \\
\hline 1 & Omission & 198 & $36.60 \%$ \\
2 & Addition & 78 & $14.42 \%$ \\
3 & Misformation & 122 & $22.55 \%$ \\
4 & Misordering & 32 & $5.91 \%$ \\
5 & Spelling & 111 & $20.52 \%$ \\
Total & & 541 & $100 \%$ \\
\hline
\end{tabular}

According to Dulay, Burt, and Krashen (1982:154), omission is the missing of an item which must occur in the sentence to form correct sentence. From 36 descriptive texts made by students, 35 students' descriptive texts contained omission. This research found 198 errors of omission after gathering all omission within the 35 student's descriptive texts. Error percentage of omission was $36.60 \%$. After deeper analysis, there were several kinds of omission found in this study. The specific types were omission of apostrophe 's, omission of article "a", omission of to be, omission of s/es for subject and verb agreement, and omission of $s$ for plural. In conclusion, this research detects 198 errors in terms of omission from 35 students' descriptive texts with percentage is $36.60 \%$. The examples of omission can be seen below. (x) $(\sqrt{ })$

1) Omission of apostrophe 's

$(\mathrm{x})$ : My father* name is Sukaarta. (Student 6 , sentence 1 )

$(\sqrt{ })$ : My father's name is Sukaarta. (Student 6 , sentence 1)

2) Omission of to be

(x) : My father's name * I Nyoman Wana. (Student 9, sentence 1)

$(\sqrt{ })$ : My father's name is I Nyoman Wana. (Student 9, sentence 1)

3) Omission of article "a"

$(x)$ : My mother is * teacher. (Student 14 , sentence 3 )

$(\sqrt{ })$ : My mother is a teacher. (Student 14 , sentence 3 )

4) Omission of s/es for subject and verb agreement

$(x)$ :Sometimes my mother go* to market to sell clothes. (Student 26, sentence 26)

$(\sqrt{ })$ : Sometimes my mother goes to market to sell clothes. (Student 26 , sentence 26)

5) Omission of $s$ for plural

$(x)$ : She is 43 year $^{*}$ old. (Student 28 , sentence 8 )

$(\sqrt{ })$ : She is 43 years old. (Student 28 , sentence 8 )

The second type of error was addition. Addition is the presence of an item which must not occur in a sentence to make it an appropriate sentence (Dulay, Burt, and Krashen, 1982:156). 
After analyzing students' descriptive texts, 26 students' descriptive texts contained addition. From calculating the total number of addition within 26 students' descriptive texts, it was found 78 errors. All addition in this research was in the category of simple addition. The error percentage of this error was $14.42 \%$. So, this research reveals 78 errors of addition from 26 students' descriptive texts with error percentage is $14.42 \%$. An example of addition can be seen below.

(x) : She is [a] short and fat. (Student 34, sentence 4)

$(\sqrt{ })$ : She is short and fat. (Student 34, sentence 4)

The third error type was misformation. According to Dulay, Burt, and Krashen (1982:158), misformation is the implementation of wrong form of item in right place of the sentence. From 36 students' descriptive texts, 32 descriptive texts had error of misformation. The total number of misformation from 32 descriptive texts made by students was 122 errors. The error percentage of misformation was $22.55 \%$. The study detected several kinds of misformation, namely: misformation of possessive pronouns, misformation of personal pronoun, misformation of gerund, misformation of article "a/an", and misformation of verb. We can conclude that the research finds 32 students' descriptive texts had misformation with total number of misformation is 122 errors in which the error percentage is $22.55 \%$. The examples of misformation can be seen below.

1) Misformation of possessive pronoun

$(x)$ : (Her) name is Bob. (Student 4, sentence 2)

$(\sqrt{ })$ : His name is Bob. (Student 4 , sentence 2)

2) Misformation of personal pronoun

$(\mathrm{x})$ : My younger sister* name is Ni Komang Deviari. (He) is 6 years old. (Student 15, sentence 2)

$(\sqrt{ })$ : My younger sister's name is Ni Komang Deviari. She is 6 years old. (Student 15, sentence 2)

3) Misformation of gerund

(x) : She likes (make) cake and bread. (Student 29, sentence 9)

$(\sqrt{ })$ : She likes making cake and bread. (Student 29, sentence 9)

4) Misformation of article "a/an"

(x) : I have (a) uncle. (Student 4, sentence 1)

$(\sqrt{ })$ : I have an uncle. (Student 4 , sentence 1 )

5) Misformation of verb

(x) : I (has) a mother. (Student 17, sentence 1)

$(\sqrt{ })$ : I have a mother. (Student 17 , sentence 1 )

The fourth error type was misordering. Misordering is the incorrect placement of a morpheme or group of morphemes in a sentence (Dulay, Burt, and Krashen, 1982:162). From analyzing students' descriptive texts, 18 texts had error of misordering. The research findings found 32 errors within those texts after searching for the total number of misordering within them. Error percentage of this error was $5.91 \%$. So, it can be seen that 18 of 36 students' descriptive texts have error of misordering with the total number of error is 32 errors and the error percentage is $5.91 \%$. an error example of misordering can be seen below.

$(x)$ : The \{colour skin\} is white. (Student 7 , sentence 7 )

$(\sqrt{ })$ : The skin colour is white. (Student 7 , sentence 7 )

The last error type was error of spelling. Sawalmeh (2013:12) states that spelling is an error in combining letters to form a word. From the analysis result, it discovered that some students contributed error related to spelling error. 33 students' descriptive texts had error of spelling within them. The calculation showed the total number of spelling from 33 student's descriptive texts was 111 errors. The percentage of this error was $20.52 \%$. In conclusion, there 
are 33 student's descriptive texts have error of spelling with the total number of error is 111 errors and the error percentage is $20.52 \%$. The error related to spelling can be seen below.

(x) : My mother is (faad). (Student 33, sentence 3)

$(\sqrt{ })$ : My mother is fat. (Student 33, sentence 3)

Looking from findings of the research, they have similarity and difference with previous researches in some terms. In term of the highest frequent error committed by students, this study got a result that omission was the highest frequent error committed by students with 198 errors or $36.60 \%$. This result is in line with the highest frequent error in the studies conducted by Putri (2013), Ervindo (2014), Ulfa et.al (2014), and Belo (2017). In their studies, omission came as the highest frequent error committed by students with percentage with $47.05 \%$, $30.12 \%, 57 \%$, and $41.06 \%$. Meanwhile, study from Wahyuni (2016) showed that the highest frequent error was misformation with $62.2 \%$. In term of the lowest frequent error committed by students, this research discovered misordering was the lowest frequent error with $5.91 \%$. Similarly, the studies conducted by Putri (2013), Azizah et.al (2014), Wahyuni (2016), and Belo (2017) had the same result. Their studies uncovered that misordering was the lowest frequent error with percentage $2.35 \%, 1 \%, 6.1 \%$, and $14.60 \%$. Meanwhile, the study from Ervindo (2014) discovered different result. The lowest frequent error in his study was misformation with $3.4 \%$.

An analysis of cause of error was carried out in this research. Purpose of doing this is to know the causes behind errors committed by students. After doing the analysis, it revealed three causes behind students' errors. The causes are carelessness, first language interference, and translation.

\begin{tabular}{cccc}
$\frac{\text { Table 2. The calculation results of error causes }}{\text { No. }}$ & $\begin{array}{c}\text { Cause of } \\
\text { Error }\end{array}$ & $\begin{array}{c}\text { The } \\
\text { Number } \\
\text { of } \\
\text { Errors }\end{array}$ & $\begin{array}{c}\text { Percentage } \\
\text { of Cause } \\
\text { of Error }\end{array}$ \\
\hline 1 & $\begin{array}{c}\text { Carelessness } \\
\text { First } \\
\text { Language }\end{array}$ & 220 & $40.67 \%$ \\
& 289 & $53.42 \%$ \\
3 & $\begin{array}{c}\text { Interference } \\
\text { Translation }\end{array}$ & 32 & $5.91 \%$ \\
Total & & 541 & $100 \%$ \\
\hline
\end{tabular}

The first cause of error was carelessness. Carelessness is related to the low motivation of students (Norrish, 1983:47). Students do not have enough motivation to know more about something. This is because either the material is not interesting or the students do not feel comfortable with their teacher's teaching styles. After doing analysis of cause of error, the analysis result found that addition, spelling, and misformation of article "a/an" were caused by carelessness. The analysis result showed that 35 students' descriptive texts contained errors caused by carelessness. From those 35 texts, error total was 220 errors and the percentage was $40.67 \%$. From the interview session with all students who did addition, 21 of 26 students admitted they had low motivation. Meanwhile, 23 of 32 students who committed error of spelling admitted that they lack of motivation. From 5 students who committed misformation of article "a/an", 4 students admitted they have low motivation. All students did not admit they lack of motivation directly. But, the lack of motivation was recognized through looking at the responses the students gave when they were being interviewed. Some students answered that they knew nothing about descriptive text when they were asked about what they know about descriptive text. Moreover, some students said that descriptive text was complicated when they were asked they like descriptive text or not. Furthermore, some students expressed that their teacher did not give attention to them, she was mean, and her teaching style was not detail enough. These responses were gained after the students were asked about if they like their teacher's teaching style when she was teaching descriptive text in the class. 
The second cause of error was first language interference. According to Norrish (1983:47), first language interference is the interference of the native language of someone when he or she learns a new language. Learning a new language could be hard for someone. This is because his or her native language interferes the process of understanding a new knowledge. As the result, he or she depends on his or her native language to understand the new language. Analysis of causes of error were carried out to find out the causes of each error type.Analysis of causes of error were carried out to find out the causes of each error type.Related to the research findings, all students writing contained errors caused by first language interference. From error cause calculation, the total error was 289 errors and the percentage was $53.42 \%$ and. It was found that several error types were caused by first language interference. The errors such as: omission of apostrophe 's, omission of to be, omission of article "a", omission of s/es for subject and verb agreement, omission of s for plural, misformation of possessive pronoun, misformation of personal pronoun, misformation of gerund, and misformation of verb. The result of the analysis was in line with the result of the interview method. The result of interview method showed all students who committed errors mentioned above admitted that they used their Indonesian language rules to make English sentences. They had different reasons why they used their native language rules instead of English grammar in making English sentences. Some of them said it was hard to use English grammar. Some of them also said it was for time efficiency and etcetera.

The last error cause was translation. This cause of error occurs when students translate their native language sentences (Indonesian sentences) into foreign language sentences (English) word by word. The students create their native language sentences. Then, they translate directly each word within their native language sentences. This happens when students have assumed the sentence formation between native language and English sentence formation is the same. After analyzing cause of error, misordering was caused by translation. There were 18 students' descriptive texts contained error caused by translation. The total number of error was 32 errors with percentage was $5.91 \%$. The result of analysis was confirmed by the result of interview session. The result of interview method showed that all students who committed misordering did translating their native language sentences word by word into English (See Appendix 7). Some of the students admitted that sometimes they translated their Indonesian sentences word by word into English when they try to make English sentences. Some of them also admitted that they always do that in making English sentences.

Related with another research, the findings of this research was in line with the causes of error found in Wahyuni's research (2016). She found three error causes, namely: carelessness, first language interference, and translation.

\section{CONCLUSIONS AND SUGGESTIONS}

This study discovered five types of grammatical errors related to Dulay, Burt, and Krashen's theory (1982:154) and Sawalmeh's (2013:10) theory. Those errors were omission, addition, misformation, misordering, and spelling. Error of omission was found in 35 students' descriptive texts with percentage was $36.60 \%$ (198 errors). The omission found consisted of omission of apostrophe 's, to be, article "a", s/es for subject and verb agreement, and s for plural. Error of addition was detected in 26 students' descriptive texts with percentage was $14.42 \%$ (78 errors). Misformation was discovered in 32 students' descriptive texts with percentage was $22.55 \%$ (122 errors). The misformation found consisted of misformation of possessive pronoun, personal pronoun, gerund, article "a/an", and verb. Error of misordering was found in 18 students' descriptive texts with percentage was $5.91 \%$ (32 errors). 111 errors were recognized as spelling with percentage $20.52 \%$. Spelling was found in 33 students' descriptive texts.

According to Norrish (1983:47), there are three error causes, namely: carelessness, first language interference, and translation. This research found that the students' errors were caused by those three causes. Addition, misformation of article "a/an", and spelling were caused by carelessness of students. First language interference caused several errors such as: 
omission (omission of apostrophe 's, to be, article "a", s/es for subject and verb agreement, and $s$ for plural), and misformation (misformation of possessive pronoun, personal pronoun, gerund, and verb). Misordering was caused by translation done by students. The calculation process showed that 35 students' descriptive texts contained errors caused by carelessness with total error was 220 errors (40.67\%). All students' descriptive texts were detected containing errors caused by first language interference with total number of error was 289 errors $(53.42 \%)$. 18 descriptive texts made by students had errors caused by translation with total number of error was 32 errors (5.91\%).

There are several suggestions given for teachers, students, and other researchers.

For teachers, there are several suggestions provided by the researcher. First suggestion is making fun atmosphere. Teachers can use games, songs, etc. to make fun teaching learning atmosphere. Second suggestion is making jargon. they can make a jargon. Example: when teacher says, "English and Indonesian", the students says loudly "different!". The third suggestion is applying consequences for translation. Teachers can make a strict rule for students who do translation. The rule also includes some consequences such as double homework, minus point, etc.

For students, the researcher has some suggestions. First is making goals. To keep students motivated. The goals such as be more active than a week ago, getting better score than yesterday, etc. Second suggestion is reading several simple English stories. Students can try to read several simple stories in order to know the way for expressing something in English.

For other researchers, they may develop more an error analysis research deeply into finding out the best way for solving students' errors especially errors found in students' writing texts.

\section{REFERENCES}

Agustina, V., \& Junining, E. (2015). Error Analysis in the Travel Writing Made by the Students of English Study Program. Journal of English Education and Language Studies, 1-28.

Al-Shujairi, Y. B., \& Tan, H. (2017). Grammar Errors in the Writing of Iraqi English Language Learners. International Journal of Education \& Literacy Studies, 122-130.

Belo, P. M. (2017). An Analysis of Grammatical Errors in Written Descriptive Text by the First Year Students of Vocational School of Economics and Commerce Becora, Dili East Timor in School Year 2016/2017. IJAR.

Divsar, H., \& Heydari, R. (2017). A Corpus-based Study of EFL Learners' Errors in IELTS Essay Writing. International Journal of Applied Linguistics and English Literature, 143149.

Dulay, H., Burt, M., \& Krashen, S. (1982). Language Two. New York: Oxford University Press.

Ervindo, A. (2014). An Analysis on the Students' Grammatical Errors in Writing Descriptive Text at the Second Year of SMPN 31 Padang. E-Journal Bung Hatta University, 1-14.

Furtina, D., Fata, I. A., \& Fitrisia, D. (2016). Grammatical Errors in Writing Task: Males VS. Females. Consortium of Asia-Pacific Education Universities, 251-258.

Gass, S. M., \& Selinker, L. (2008). Second Language Acquisition: An Introductory Course. New York: Routledge.

Golkova, D., \& Hubackova, S. (2014). Productive Skills in Second Language Learning. Procedia, 477-81.

Greenbaum, S., \& Nelson, G. (2002). An Introduction to English Grammar. Great Britain: Pearson Education Limited. 
Hermini. (2015). Grammatical Error Analysis in Recount Texts Made by the Students of Cokroaminoto University of Palopo. Ethica Lingua, 87-101.

Hsu, C. H. (2013). Revisiting Causes of Grammatical Errors for ESL Teachers. Edcational Research, 513-516.

Isa, Q. N., Risdaneva, \& Alfayed, A. (2017). An Analysis of Acehnese EFL Students' Grammatical Error in Writing Reount Texts. Englisia, 41-50.

Jabeen, A., Kazemian, B., \& Mustafai, M. S. (2015). The Role of Error Analysis in Teaching and Learning of Second and Foreign Language. Education and Linguistics Research, 52-61.

Khan, S. R., \& Khan, M. R. (2016). Error Analysis in English Writing. International Multidisciplinary Research Journal, 232-243.

Moqimipour, K., \& Shahrokhi, M. (2015). The Impact of Text Genre on Iranian Intermediate EFL Students' Writing Errors: An Error Analysis Perspective. Canadian Center of Science and Education, 122-137.

Norrish, J. (1987). Language Learners and Their Errors. London: Macmillan.

Nunan, D. (2003). Practical English Language Teaching. New York: McGraw Hill.

Putri, P. S., \& Dewanti, A. (2014). An Analysis of Grammatical Errors in Writing Narrative Texts Done By the Second Semester Students at the Diploma Program English Department in Airlangga University Surabaya. Anglicist, 1-7.

Putri, Y. F. (2013). Students' Errors in Using Simple Present Tense in Writing Descriptive Texts. AL-TA'LIM Journal, 1-18.

Sawalmeh, M. H. (2013). Error Analysis of Written English Essays: the Case of Students of the Preparatory Year Program in Saudi Arabia . English for Specific Purposes World, 1-17.

Silalahi, M., Rafli, Z., \& Rasyid, Y. (2018). The Analysis of Errors in Translation of Scientific Text from English to Indonesian Language. Journal of Education, Teaching and Learning, 23-27.

Silalahi, R. M. (2014). Error Analysis on Information and Technology Students' Sentence Writing Assignments. IJEE, 151-166.

Taslim, F. (2016). Improving Students' Mastery on Simple Present Tense Through Climbing Grammar Mountain Game. Al-Ta'lim Journal, 146-155.

Ulfa, N. A., Bindarti, W. E., \& Suharjito, B. (2014). Grammatical Error Analysis of the Eighth Grade Students in Writing Descriptive Text at SMP Negeri 1 Jember in the 2013/2014 Academic Year. Artikel IImiah Mahasiswa, 1-3.

Wahyuni, K. S. (2016). An Analysis of Grammatical Errors Made by The Eighth Grade Students of SMP Ayodhya Pura Selat in Writing Descriptive Texts in Academic Year 2015/2016. Singaraja: Ganesha University of Education. 